\title{
Floral Homeostasis Breakdown in Endangered Plant Valeriana jatamansi Jones (Valerianaceae) in North Eastern Himalayan Region
}

\author{
Soumendra Chakraborty ${ }^{*}$, Dhiman Mukherjee ${ }^{2}$, Sibdas Baskey ${ }^{3}$ \\ ${ }^{1}$ Division of Genetics and Plant Breeding, Uttar Banga Krishi Viswavidyalaya, Pundibari, India \\ ${ }^{2}$ Division of Agronomy, Uttar Banga Krishi Viswavidyalaya, Pundibari, India \\ ${ }^{3}$ Division of Plant Pathology, Uttar Banga Krishi Viswavidyalaya, Pundibari, India \\ Email: "soumendra1@gmail.com
}

Received 23 October 2015; accepted 7 December 2015; published 10 December 2015

Copyright (C) 2015 by authors and Scientific Research Publishing Inc.

This work is licensed under the Creative Commons Attribution International License (CC BY). http://creativecommons.org/licenses/by/4.0/

(c) $\underset{\mathrm{EY}}{\text { (7) }}$ Open Access

\section{Abstract}

An inhabitant of north western Himalayan region and a gynodioceious plant having a lot of medicinal properties, Valeriana jatamansi Jones (Valerianaceae) is an enlisted endangered plant in the world. It was introduced in the research station of North Bengal Agricultural University $\left(27.06^{\circ} \mathrm{N} \mathrm{88.47}{ }^{\circ} \mathrm{E}\right)$ situated in north eastern Himalayan region of Darjeeling district in the state of West Bengal from Sikkim Sangtok $\left(27^{\circ} 25^{\prime} \mathrm{N} \mathrm{88^{ \circ } 3 1}\right.$ 'E) of north Sikkim area in India for the purpose of conservation. As we noticed some irregular development of floral organs, we investigated some pertinent questions regarding ecological aberrations found in plants. We found plants introduced in north eastern Himalayan region changed their homology of number flower petals and position of stamens seen naturally in north western Himalayan region as per the reports. Was there any genetic or extreme environmental stress condition caused a sudden change in floral structure as it is generally known as a rare phenomenon and frequently not seen? What were the correlations of different floral parts and fitness of population in different morphotypes? We predicted possible outcomes of seed setting by univariate regression models in a particular environment in addition to this investigation. We proposed three models of heterozygousity for answering the reasons of unstable floral form from a general known floral form, where silent mutations help the plants to survive in adverse conditions in spite of deformed or variable formed of floral morphology.

\section{Keywords}

Floral Homeostasis, Deformed Flower Morphology, Conservation, Endangered Medicinal Plant,

${ }^{*}$ Corresponding author.

How to cite this paper: Chakraborty, S., Mukherjee, D. and Baskey, S. (2015) Floral Homeostasis Breakdown in Endangered Plant Valeriana jatamansi Jones (Valerianaceae) in North Eastern Himalayan Region. American Journal of Plant Sciences, 6, 3119-3138. http://dx.doi.org/10.4236/ajps.2015.619304 


\section{Fitness of Population, Silent Mutation}

\section{Introduction}

Valeriana jatamansi Jones is a known endangered plant in the world [1]-[5]. It is gynodioceious in nature [4]-[6]. The plant belongs to the family Valerianaceae and it has almost 350 sps distributed throughout the world except Australia and New Zealand [4]. This plant is mostly found in higher altitudes with many species in higher alpine zones [4]. The female plants were found to have pistillate flowers without an androceium and four white (large) or tinged with pink (small) petals [4] [5] [7]-[9]. In North Western Himalayan region, hermaphrodite plants were reported to have five petals and three stamens that are epipetalous and opposite to the corolla lobes and female plants were found to have four petals and not five like hermaphrodite (Table 1) [4]-[6] [8]-[10]. However, we found the abrupt appearance of four and five petals randomly in the inflorescences of flowers in hermaphrodite plants and also in female plants (Figure 1 and Figure 2). They were not seen in each and every flower of the inflorescence. Stamens were also located in between the petal spaces of the flower as it was otherwise reported [4] [5] [9] [10]. They were reported to be found in white, long prominently larger than pistillate flower (Table 1) [4] [5]. Anthesis was observed 3 - 4 days earlier in female flowers than hermaphrodite flowers [6] [11]. Anthesis of female flowers was reported to be found earlier than hermaphrodite flowers in the elevations of KUBG (Kashmir University Botanical Garden) (1490 m asl), Ferozpura (2150 m asl) and found at the same time in Gulbarg (2650 m asl), Kashmir [10] in different elevations [6].

Origin of the plant material: The plant was introduced in the research station by collecting seedlings from Sangtok $\left(27^{\circ} 25^{\prime} \mathrm{N} 88^{\circ} 31^{\prime} \mathrm{E}\right)$, North Sikkim, for the purpose of conservation programme as per the work programme planned by Directorate of Medicinal and Aromatic Plants Research (DMAPR), a body developed by ICAR (Indian Council of Agricultural Research) with the sole purpose of collection and conservations programmes of medicinal and aromatic plants including rare endangered medicinal plant species in their natural habitats by constructing field gene banks and other necessary facilities to protect them from natural damage or extinction from the country and the world [12] [13].

The overall objective of our study is to find out reasons behind divulging the natural process of formation of floral structure in the plant Valeriana jatamansi Jones in this new region from what it is generally reported [4] [5] [9] [10] because floral development genes were found to be somewhat obstinate genes which was not frequently reported to be found changed in different environments [14]-[21].

We divided process of investigations into following headings:

1) The random relative change in floral morphology in some of the flowers in both types of sexes of the plant (Figure $1 \&$ Figure 2).

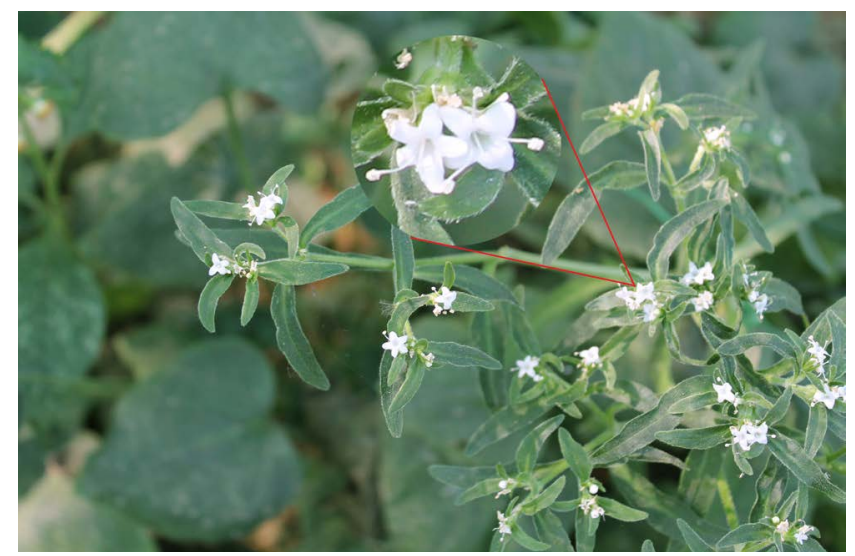

Figure 1. The character of flowers where in hermaphrodite flower it was found to have both type of flowers having four and five number of petals; the stamens are found in between the petal spaces; this was found to be nature's disruption of stabilizing selection in which deformed and random development of the reproductive organs were found due extreme environmental stress in the new environment. 


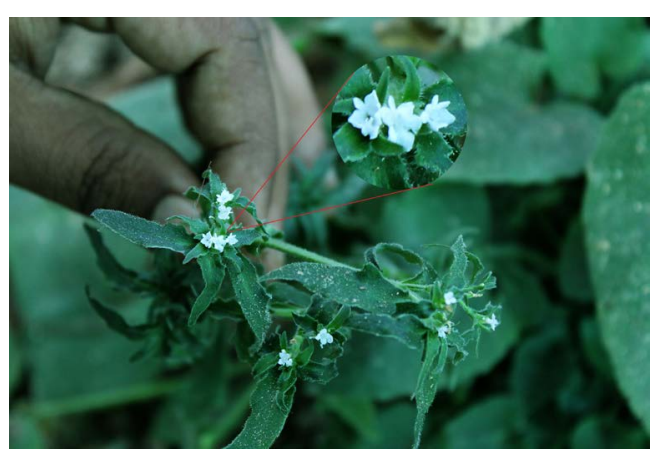

Figure 2. The female plant having flowers having four and five number of petals in the same plant which also resembling the same pattern of evolution as was found in hermaphrodite plant (Figure 1); the evolutionary process was found going on in this region.

Table 1. Structural differences of flower found in the ex-situ conservation in Regional Research Station, Kalimpong (3000 ft asl).

\begin{tabular}{|c|c|c|c|}
\hline \multicolumn{2}{|c|}{ Structure of Hermaphrodite Flower } & \multicolumn{2}{|c|}{ Structure of Female flower } \\
\hline $\begin{array}{l}\text { Commonly found in other } \\
\text { sporadic fragmented } \\
\text { populations in } \\
\text { Kashmir hills [9] [10] }\end{array}$ & $\begin{array}{l}\text { Found in the Regional } \\
\text { Research station field } \\
\text { gene bank [11] (Figure 1) }\end{array}$ & $\begin{array}{l}\text { Commonly found other } \\
\text { sporadic fragmented } \\
\text { populations in Kashmir } \\
\text { hills [9] [10] }\end{array}$ & $\begin{array}{l}\text { Found in the Regional } \\
\text { Research station } \\
\text { field gene bank } \\
\text { [11] (Figure 2) }\end{array}$ \\
\hline $\begin{array}{l}\text { Size is larger than } \\
\text { female flower }\end{array}$ & Size is larger than female flower & $\begin{array}{l}\text { Size is smaller } \\
\text { than hermaphrodite flower }\end{array}$ & $\begin{array}{l}\text { Size is smaller than } \\
\text { hermaphrodite flower }\end{array}$ \\
\hline $\begin{array}{l}\text { Calyx is persistant, leafy } \\
\text { pappus and reduced to small } \\
\text { tooth-like structures. }\end{array}$ & $\begin{array}{l}\text { Same calyx morphology was observed } \\
\text { in this hermaphrodite population }\end{array}$ & $\begin{array}{l}\text { Calyx is persistent, leafy pappus } \\
\text { and reduced to small tooth-like } \\
\text { structures. }\end{array}$ & $\begin{array}{l}\text { Same calyx morphology was } \\
\text { observed in this female plant } \\
\text { population }\end{array}$ \\
\hline $\begin{array}{l}\text { pappus like Petal } \\
\text { actinomorphic, } \\
\text { arrangement, epipetalous. } \\
\text { Five in numbers. }\end{array}$ & $\begin{array}{l}\text { Petals actinomorphic, } \\
\text { epipetalous and five and four in } \\
\text { numbers (Figure } 1 \text { ). }\end{array}$ & $\begin{array}{l}\text { Petals actinomorphic } \\
\text { and four in numbers. }\end{array}$ & $\begin{array}{l}\text { Petals actinomorphic and } \\
\text { five and four in } \\
\text { numbers. (Figure 2) }\end{array}$ \\
\hline $\begin{array}{c}\text { Androceium and } \\
\text { gynoceium present } \\
\text { Unifid stigma is present, } \\
\text { stamens are epipetalous, } \\
\text { three in number present } \\
\text { opposite to petals. Petals are } \\
\text { larger than female flower. }\end{array}$ & $\begin{array}{l}\text { Androceium and gynoceium } \\
\text { present. Unifid stigma is present; } \\
\text { stamens are epipetalous, } \\
\text { three in number in between the } \\
\text { gaps of petals inside the flower, } \\
\text { not exactly opposite to the } \\
\text { petals (Figure 1). Petals are } \\
\text { larger than female flower. }\end{array}$ & $\begin{array}{l}\text { Androceium-Absent } \\
\text { Gynocium-Present. Trifid } \\
\text { stigma is seen having } \\
\text { three prongs extended from } \\
\text { middle of the style in } \\
\text { female flowers, Petals are } \\
\text { smaller than } \\
\text { hermaphrodite flower. }\end{array}$ & $\begin{array}{l}\text { Androceium-Absent } \\
\text { Gynoceium-Present } \\
\text { Trifid stigma is seen having } \\
\text { three prongs extended } \\
\text { from the upper portion } \\
\text { of the style (Figure 2). } \\
\text { Petals are smaller than } \\
\text { hermaphrodite flower. }\end{array}$ \\
\hline $\begin{array}{l}\text { Generally visiting } \\
\text { pollinators are } \\
\text { hemipterean } \\
\text { and dipterean insects }\end{array}$ & $\begin{array}{l}\text { Hymenopteran and } \\
\text { Hemipterean visiting pollinators } \\
\text { like rock bees, bumble bees, } \\
\text { flies were visitors }\end{array}$ & $\begin{array}{l}\text { Same is found in female } \\
\text { flowers like } \\
\text { hermaphordite flowers }\end{array}$ & $\begin{array}{l}\text { Same is found in female } \\
\text { flowers where hemipteran } \\
\text { pollinators were found to visit }\end{array}$ \\
\hline $\begin{array}{l}\text { Anthesis varies from } \\
\text { place to place and } \\
\text { asynchronous flowering } \\
\text { was seen }\end{array}$ & $\begin{array}{c}\text { Anthesis was found } \\
\text { between } 6 \text { - } 8 \text { AM. } \\
\text { asynchronous flowering } \\
\text { was seen }\end{array}$ & $\begin{array}{l}\text { Anthesis varies from } \\
\text { place to place. asynchronous } \\
\text { flowering was seen }\end{array}$ & $\begin{array}{l}\text { Anthesis was found between } \\
6 \text { - } 8 \text { PM. and anthesis was } \\
\text { found } 3 \text { - } 4 \text { days earlier } \\
\text { than hermaphrodite flowers. }\end{array}$ \\
\hline $\begin{array}{l}\text { The ranges were reported } \\
\text { within the same range } \\
\text { found in Kalimpong }\end{array}$ & $\begin{array}{l}\text { Size of the flowers was } \\
\text { found to be } 7 \text { - } 9 \mathrm{~mm} \text { in length. }\end{array}$ & $\begin{array}{l}\text { Size of the flowers were found to } \\
\text { be } 3-4 \mathrm{~mm} \text {. in length. }\end{array}$ & $\begin{array}{c}\text { The ranges were reported within } \\
\text { the same range found in } \\
\text { Kalimpong }\end{array}$ \\
\hline $\begin{array}{l}\text { The same structural } \\
\text { features were reported. }\end{array}$ & $\begin{array}{l}\text { The flowers were found to be } \\
\text { heterostylous in nature. Length of the } \\
\text { style and length of filaments were } \\
\text { found to be different. Length of the } \\
\text { filaments bearing anthers was } \\
\text { found to have longer in length } \\
\text { than the length of the style. }\end{array}$ & $\begin{array}{l}\text { The same structural } \\
\text { features were reported. }\end{array}$ & $\begin{array}{l}\text { The lengths of styles are } \\
\text { larger than petal length. }\end{array}$ \\
\hline $\begin{array}{c}\text { The ranges were reported } \\
\text { within the same range found in } \\
\text { Kalimpong }\end{array}$ & $\begin{array}{l}\text { Length of the filament was recorded } \\
4 \text { - } 5 \mathrm{~mm} \text {. in length. Length of style } \\
\text { was recorded } 3 \text { - } 4 \mathrm{~mm} \text { in length }\end{array}$ & $\begin{array}{l}\text { The ranges were reported } \\
\text { within the same range } \\
\text { found in Kalimpong. }\end{array}$ & $\begin{array}{c}\text { Length of the style } \\
\text { was recorded } 3-4 \mathrm{~mm}\end{array}$ \\
\hline
\end{tabular}


2) Relationship between floral traits and seed setting in a new environment (Tables 2-4, Table A1 and Figures 3(a)-(e)).

i) In the first case we discussed the reasons behind it (Model 1, Model 2 and Model 3) where we found its changes in floral biology in both the types of sexes of the plant. Natural history or population biology of the species in question or developmental mechanisms of the species should be understood before justifying the changes due to DI which was earlier reported [4] [5] [9] [10]. [15]-[21] found phenovarients in floral morphology in their experimental organisms in different places where deformation of reproductive organs reported due to environmental insults like us. The photoperiod length and maximum and minimum temperatures are given in (Table 4) due to which environmental insults were found in this region for the plant's adaptation.

ii) In the second case, relationship between different floral traits with seed setting was investigated (Table 2, Table 3, Figures 3(a)-(e) and Table A1). The effect of floral organs in fitness of population was found [17] [22]-[25] in different regions of the world.

Table 2. Quantitative parameters of flower and seed wt of Valeriana jatamansi Jones.

\begin{tabular}{|c|c|c|c|c|c|c|c|c|c|c|c|c|c|c|}
\hline $\begin{array}{c}\text { Plant } \\
\text { mophotype }\end{array}$ & $\begin{array}{c}\text { Type } \\
\text { of } \\
\text { plant }\end{array}$ & $\begin{array}{c}\text { Length } \\
\text { of } \\
\text { sepal } \\
(\mathrm{mm} .)\end{array}$ & $\begin{array}{c}\text { Breadth } \\
\text { of } \\
\text { sepal } \\
(\mathbf{m m} .)\end{array}$ & $\begin{array}{c}\text { Length } \\
\text { of } \\
\text { corolla } \\
(\mathbf{m m} .)\end{array}$ & $\begin{array}{c}\text { Breath } \\
\text { of } \\
\text { corolla } \\
(\mathrm{mm} .)\end{array}$ & $\begin{array}{l}\text { Length } \\
\text { of style } \\
\text { (mm.) }\end{array}$ & $\begin{array}{c}\text { Length } \\
\text { of } \\
\text { stigma } \\
\text { (mm.) }\end{array}$ & $\begin{array}{c}\text { Breadth } \\
\text { of stigma } \\
\text { (mm.) }\end{array}$ & $\begin{array}{c}\text { Length } \\
\text { of } \\
\text { stamen } \\
\text { (mm.) }\end{array}$ & $\begin{array}{l}\text { Length } \\
\text { of the } \\
\text { anther } \\
\text { sac } \\
\text { (mm.) }\end{array}$ & $\begin{array}{l}\text { Breadth } \\
\text { of the } \\
\text { anther } \\
\text { sac (mm.) }\end{array}$ & $\begin{array}{c}\text { Flower } \\
\text { length } \\
\text { (mm.) }\end{array}$ & $\begin{array}{c}\text { No. of } \\
\text { flowers/ } \\
\text { plant }\end{array}$ & $\begin{array}{c}\text { Seed } \\
\text { wt/plant } \\
\text { (mg.) }\end{array}$ \\
\hline
\end{tabular}

Plants
having
entire
leaf
margin

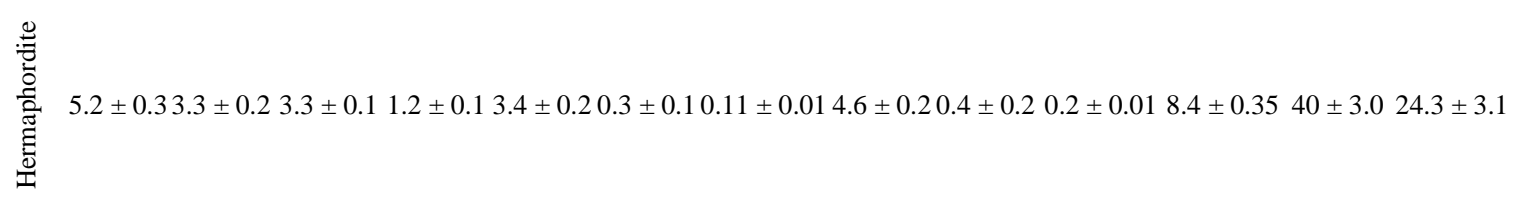

Female 5.1 $\pm 0.12 .5 \pm 0.11 .3 \pm 0.3 \quad 0.5 \pm 0.14 .1 \pm 0.30 .4 \pm 0.10 .14 \pm 0.01 \quad 0.0 \quad 0.0 \quad 0.0 \quad 4.3 \pm 0.2 \quad 38 \pm 4.0 \quad 35.2 \pm 1.8$

Plants

having

sinuate

leaf

margin

营

Female4.8 $\pm 0.11 .2 \pm 0.31 .7 \pm 0.10 .8 \pm 0.14 .2 \pm 0.10 .3 \pm 0.10 .13 \pm 0.01 \quad 0.0 \quad 0.0 \quad 0.0 \quad 3.9 \pm 0.3 \quad 36 \pm 2.0 \quad 31.4 \pm 2.6$

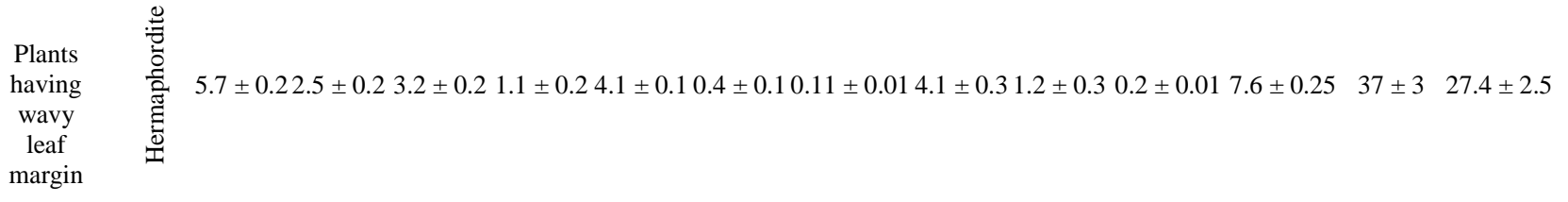

Female $5.4 \pm 0.32 .1 \pm 0.21 .6 \pm 0.10 .6 \pm 0.14 .2 \pm 0.10 .3 \pm 0.10 .12 \pm 0.01 \quad 0.0 \quad 0.0 \quad 0.0 \quad 3.1 \pm 0.3 \quad 32 \pm 3.0528 .5 \pm 2.8$

Floral traits and their Standard Deviation values.

Table 3. Correlation matrix of Valeriana jatamansi Jones.

\begin{tabular}{|c|c|c|c|c|c|c|c|c|c|c|}
\hline & $\begin{array}{l}\text { Length Breadth } \begin{array}{c}\text { Length } \\
\text { Breath } \\
\text { of sepal of sepal }\end{array} \begin{array}{c}\text { of } \\
\text { corolla }\end{array} \\
\text { corolla }\end{array}$ & $\begin{array}{l}\text { Length } \\
\text { of style }\end{array}$ & $\begin{array}{l}\text { Length } \\
\text { of } \\
\text { stigma }\end{array}$ & $\begin{array}{l}\text { Breadth } \\
\text { of } \\
\text { stigma }\end{array}$ & $\begin{array}{l}\text { Length } \\
\text { of } \\
\text { stamen }\end{array}$ & $\begin{array}{c}\text { Length } \\
\text { of the } \\
\text { anther sac }\end{array}$ & $\begin{array}{c}\text { Breadth } \\
\text { of the } \\
\text { anther sac }\end{array}$ & $\begin{array}{l}\text { Flower } \\
\text { length }\end{array}$ & $\begin{array}{l}\text { No. of } \\
\text { flowers }^{-1} \\
\text { plant }\end{array}$ & $\begin{array}{l}\text { Seed } \\
\text { wt }^{-1} \\
\text { plant }\end{array}$ \\
\hline \multicolumn{11}{|l|}{$\begin{array}{l}\text { Length } \\
\text { of sepal }\end{array}$} \\
\hline $\begin{array}{c}\text { Breadth } \\
\text { of sepal }\end{array}$ & 0.472 & & & & & & & & & \\
\hline
\end{tabular}




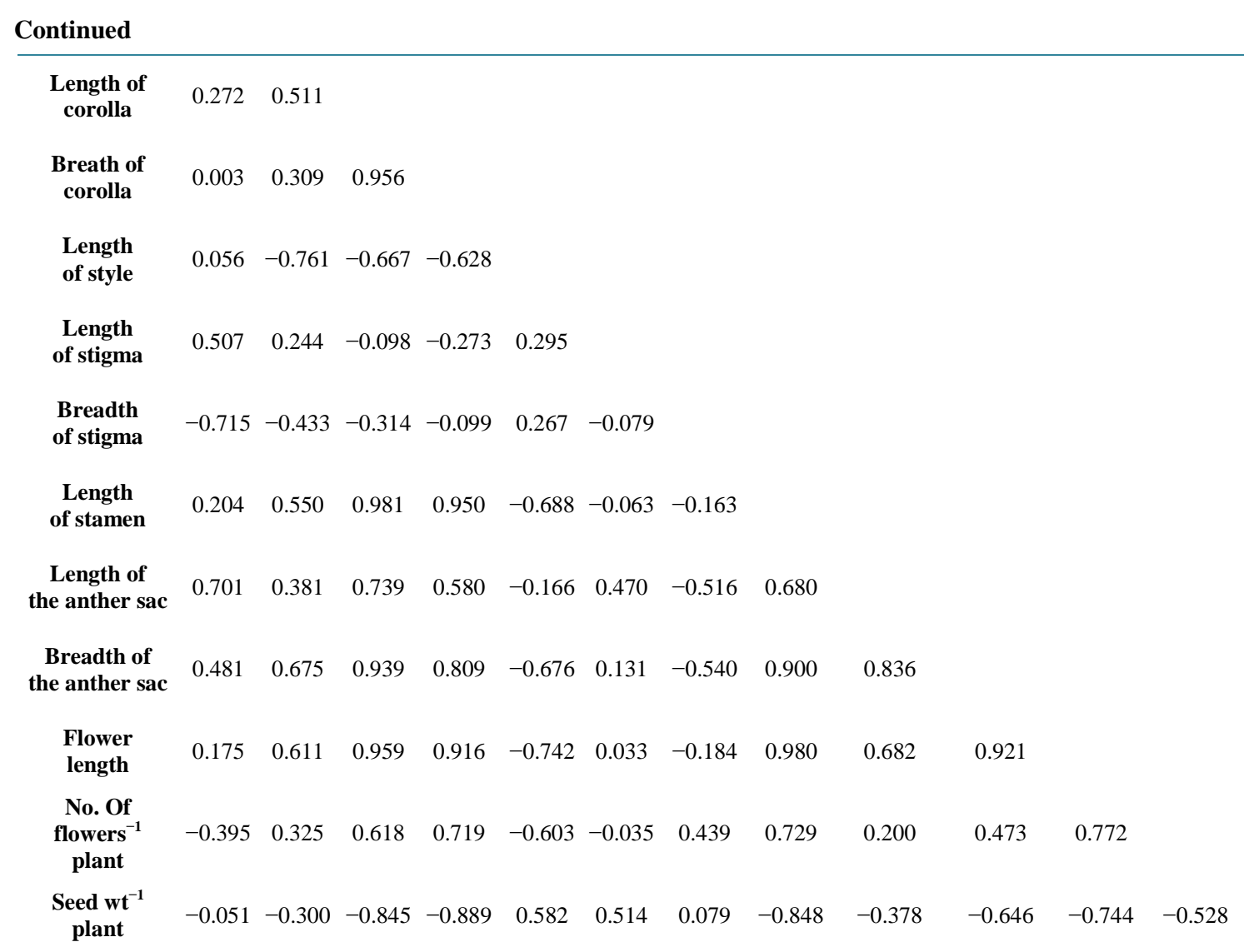

Table 4. Average Weather data and Mean day length: April 2012-March 2014.

\begin{tabular}{|c|c|c|c|c|c|c|}
\hline & \multicolumn{2}{|c|}{ Temperature $^{\circ} \mathrm{C}$} & \multicolumn{2}{|c|}{ RelativeHumidity } & \multirow{2}{*}{$\begin{array}{c}(\%) \\
\text { Rainfall (mm) }\end{array}$} & \multirow{2}{*}{$\begin{array}{l}\text { Day length } \\
\text { (hrs }^{-1} \text { day) }\end{array}$} \\
\hline & Min & Max & Min & Max & & \\
\hline April & 15.2 & 27.3 & 75.5 & 81.9 & 12.42 & 11.30 \\
\hline May & 19.3 & 32.2 & 81.6 & 90.5 & 13.69 & 12.10 \\
\hline June & 22.2 & 33.0 & 82.5 & 92.9 & 286.20 & $12 . .35$ \\
\hline July & 23.1 & 33.3 & 96.0 & 98.1 & 309.55 & 13.10 \\
\hline August & 22.0 & 32.8 & 91.5 & 96.5 & 468.10 & 12.45 \\
\hline September & 19.9 & 29.9 & 80.9 & 92.4 & 289.14 & 11.40 \\
\hline October & 18.8 & 28.0 & 77.5 & 89.9 & 130.11 & 11.35 \\
\hline November & 12.6 & 23.3 & 73.9 & 76.9 & 5.01 & 11.15 \\
\hline December & 6.4 & 15.1 & 79.9 & 89.3 & 1.40 & 10.30 \\
\hline January & 5.6 & 16.6 & 74.5 & 80.1 & 1.02 & 10.40 \\
\hline February & 10.6 & 20.1 & 82.1 & 86.9 & 0.02 & 11.05 \\
\hline March & 12.1 & 24.1 & 80.2 & 83.2 & 0.91 & 11.15 \\
\hline
\end{tabular}

Data are from Automated Meteorological Laboratory, Regional Research Station, Uttar Banga Krishi Viswavidyalay, Kalimpong, Darjeeling West Bengal, India. 


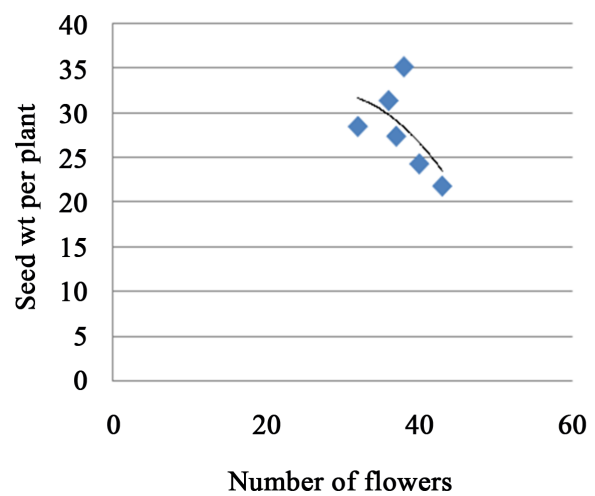

$$
\begin{aligned}
& y=2.272 x \\
& R^{2}=0.395
\end{aligned}
$$

- Seed wt/plant

— Poly. (Seed wt/plant)

(a)

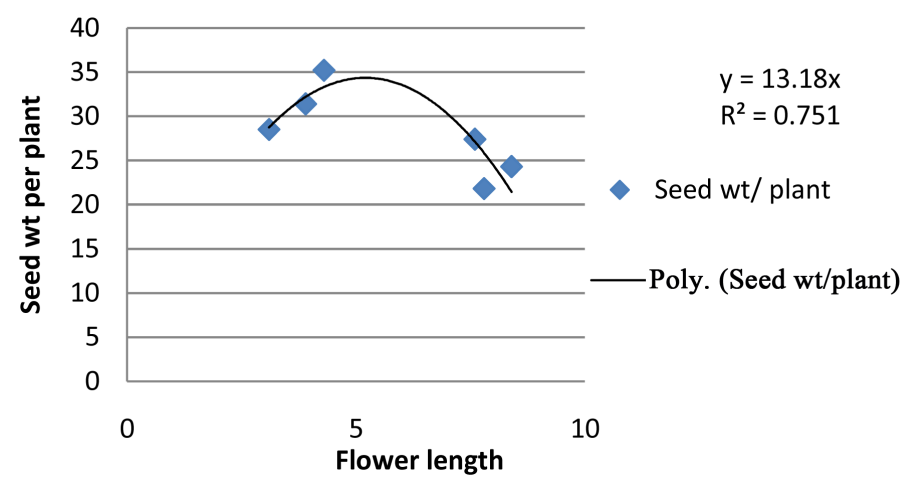

(b)

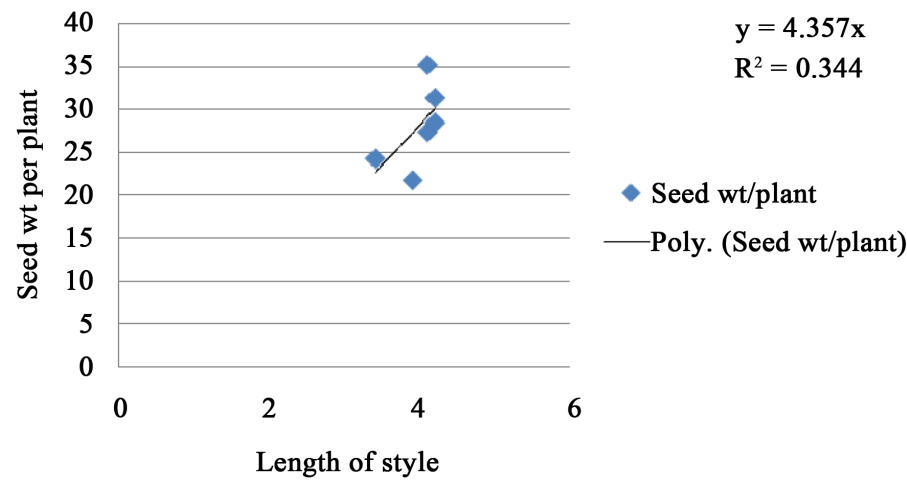

(c)

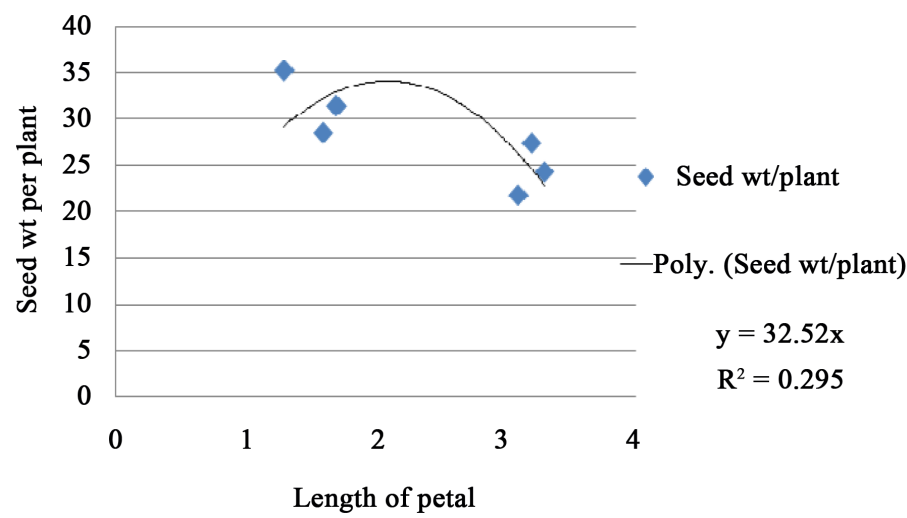

(d) 


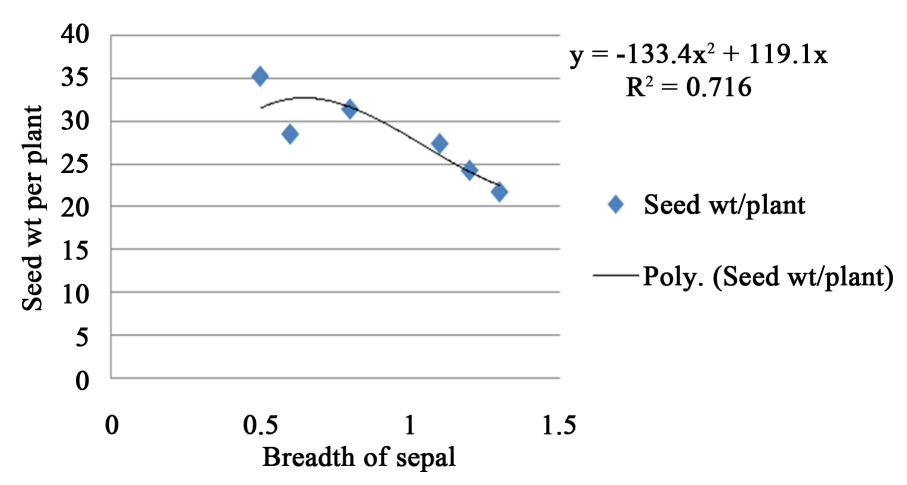

(e)

Figure 3. (a) $2^{\text {nd }}$ order Polynomial function of number of flowers ${ }^{-1}$ plant. All the flowers from three types of morphs showed a negative trend in both hermaphordite and female plants. Though there are some outlayers which may be number of flowers in female plants which cannot be predicted; Coefficient of determination $\mathrm{R}^{2}=0.395$; significant at $95 \%$; (b) $2^{\text {nd }}$ order polynomial function of flower length; Co-efficient of determination $\mathrm{R}^{2}=0.751$; significant at $95 \%$ level; All the flowers of from three morphs from both hermaphordite and female plants has positive trendline upto a certain value after which negative trend will follow in case of length of flower. Higher value of coefficient of determination will explain $75.1 \%$ of the observed value for prediction of seed wt; (c) Here positive trendline was found and length of the style was found to have positive trend with seed wt per plant in $2^{\text {nd }}$ order polynomial function of length of style; Co efficient of determination $\mathrm{R}^{2}=0.344$; significant at $95 \%$ level of confidence; (d) $2^{\text {nd }}$ order polynomial function of length of petal; Here flowers of female and hermaphrodite plants show from all three morphs more of a negative trend. There are out layers which signify the trend may not be explained in female plants. Coefficient of determination $\mathrm{R}^{2}=0.295$; significant in $95 \%$ level of confidence. Coefficient of determination is also low; (e) Here negative trend line was found and breadth of the petal was found to have negative trend for predicting seed wt per plant of $3^{\text {rd }}$ order polynomial function of breadth of corolla; significant at 95\% level of confidence. Coefficient of determination $\mathrm{R}^{2}=0.716 ; 71.6 \%$ of the result can be explained for prediction of seed wt per plant which is quite strong.

(i)

\section{Presence of minimum heterozvgosity}

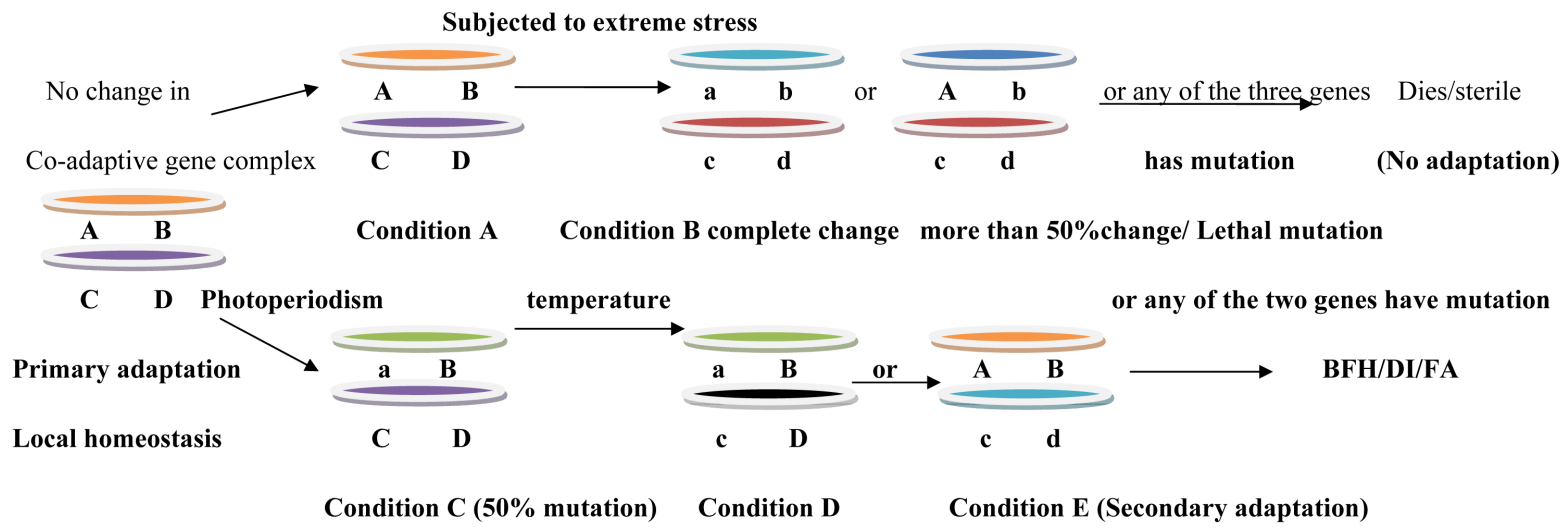

Model 1. Conditions of heterozygousity.

(i) Presence of more heterozygous condition-(Generalised condition)

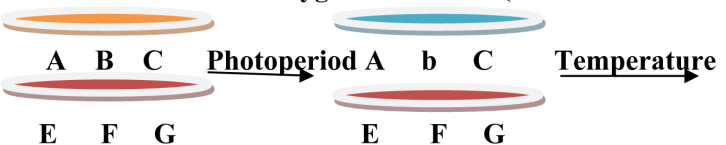

Local homeostasis

Primary adaptation initiation of flowering stage

Silent mutation

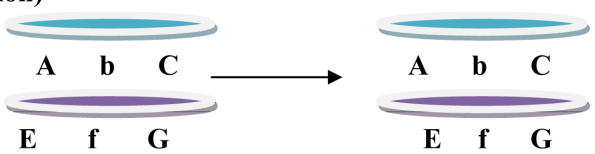

Formation of flower

Production of seeds/fitness of a plant

Silent mutation

Secondary adaptation

Model 2. Conditions of heterozygousity. 
(i) Presence of more heterozygous condition (Specific condition)

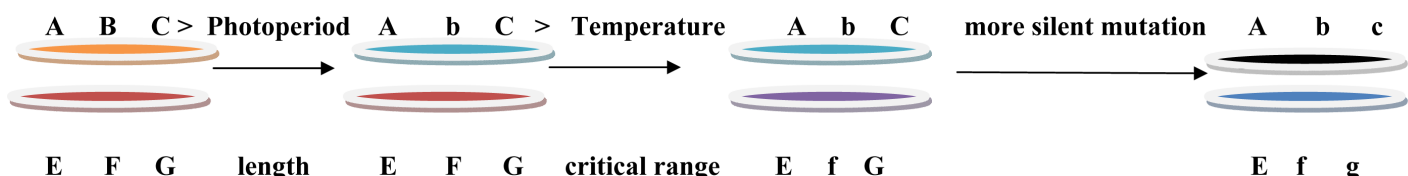

Local homeostasis

Initiation of flowering stage

Formation of flower Formation of BFH/DI/FA/ formation of seeds

Model 3. Condition of heterozygousity.

\section{Materials and Methods}

\subsection{Geographical Position of the Study Site at Research Station}

The hill zone of West Bengal, India, as one of the six parts of the different geographical zones comprising of three hilly subdivisions, Darjeeling $\left(27^{\circ} 3^{\prime} \mathrm{N} 88^{\circ} 16^{\prime} \mathrm{E}\right)$, Kalimpong $\left(27.06^{\circ} \mathrm{N} 88.47^{\circ} \mathrm{E}\right)$ and Kurseong $\left(26^{\circ} 52^{\prime} 40^{\prime \prime} \mathrm{N}\right.$ $\left.88^{\circ} 16^{\prime} 38^{\prime \prime} \mathrm{E}\right)$ which is situated in northern part of the state West Bengal. The geographical area of this zone is about $3115 \mathrm{sq} \mathrm{km}$, which is $3.5 \%$ of the total state area. The elevation of the site is about $3150 \mathrm{mt}$. above sea level. The highest average rainfall varies from 2500 - $3000 \mathrm{~mm}$ of which $80 \%$ is received during June to September. Snowfall during first half of January is also very common in areas above $2200 \mathrm{~m}$ above sea level. The average maximum and minimum temperatures round the year recorded $34^{\circ} \mathrm{C}$ and $7^{\circ} \mathrm{C}$ respectively (Table 4).

\subsection{Measurement of Flower Morphotype}

A plant would survive in a new environment could only be interpreted by its fitness or the ability of forming seeds [17] [23]. Flower morphology was recorded by sampling [23] 30 plants per morphotype (populations of entire leaf margin, sinuate leaf margin and wavy leaf margin) where, from each plant five flowers were recorded. After recording, the average of five flowers in each plant and consequently total average of flowers were done in 30 plants in each of the morphotype population. The three types of morphs were taken into consideration to find out any relevance of difference of results present if any. The results of the floral parameters were given in Table 2. [16] and [26] suggested in their investigations particularly taking into account of different floral parameters in a zoophilous plant and Penstemon centranthifolius of Scorphulariaceae family respectively about the contributing effects of floral parameters on fitness of the population and also type of selection by nature.

The flower parts were taken into account in hermaphrodite and female flowers were i) length, breadth and number of sepals, ii) length, breadth and number of petals iii) length and number of stamens iv) length, breadth and number of anthers v) length and number of style, vi) length, breadth and number of stigma and vii) total length of the flower and viii) total number of flowers in a single plant (Table 2) [16] [17] [22] [23] [26].

The measurement of flower parts was conducted by venire calliper scale to record the observations of the parameters of flowers of both hermaphrodite and female flowers (Table 2). Numbers of flowers were also taken both in hermaphrodite and female plant and correlation of seed wt with each parameter were done to find out if any relationship with any of the floral trait was found at all in this region.

\subsection{Correlation Analysis}

Correlation matrix in SPSS software was measured for each of the floral traits and relationship between each one of them (Table 3). We also did correlation analysis to identify the magnitude of influence of flower parameters for fitness of a single plant. Relationship of each floral parameter was found as it signals the process of evolutionary phenomenon of selection of nature of a plant during the period of domestication [22] [23].

\subsection{Univariate Regression Model}

The validity of regression model for predicting successful pollination and seed set in a plant was one of the methods for finding out the role of floral traits for pollination by animals or insects in many previous reported investigations [17] [22]-[25] which was investigated in addition to the investigations of breakdown of floral homeostasis in this plant.

Seed yield or seed setting in a plant is the most important signal for domestication of a plant in a new region 
[22]. [27] utilized a regression model where he did linear regression model while investigating different floral traits and fruit size among the various species of genus Phacelia. Regression analysis was done with each parameter to find out the predictability of the effect of flower parameters with respect to seed yield of the plant. Scatter diagrams were observed to infer the relationship between each parameter and the seed wt of the plant (Figures 3(a)-(e)). Here non-parametric relationships were found to be better fitted for the regression analysis of some floral parameters depending on the $\mathrm{r}^{2}$ (co-efficient of variation) values.

\section{Results and Discussion}

\subsection{The Change in Floral Morphology}

It was earlier reported in Linanthus sps., variable expression in petal numbers [15], in Eichhornia panuculata variable expression in petal numbers was reported [19] and in Mimulus guttatus, variable expression of size of floral organs was found [20], it was not found or reported by ecologists or scientists very frequently.

From the ecological point of view, the ability of organisms to withstand different environmental insults or stress to produce a predictable phenotype is named as developmental homeostasis [28] [29]. The generalisation of overall process can be presented as a schematic diagram in the following way:

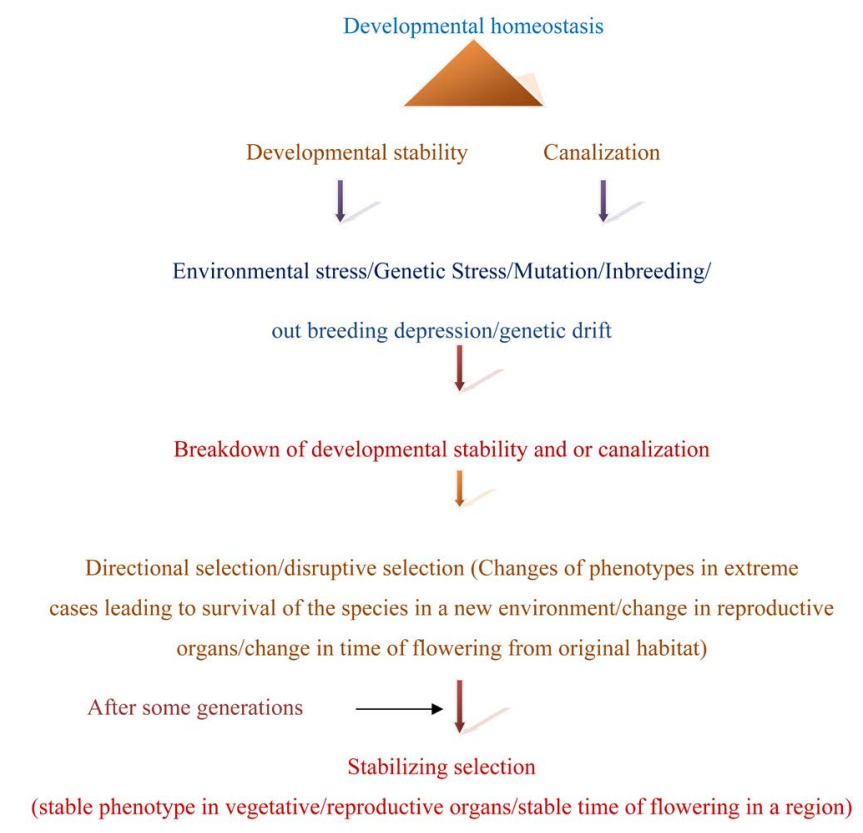

\section{Flow chart}

Developmental instability is known to be the estimator of genetic stress [30] which results in disruptive selection and development of deformed structure of floral organs, although quantification developmental homeostasis due to genetic effect is very complex and difficult to explain clearly. [30] gave a view of quantification by measuring out the variability of genetical or phenotypical variance $(\mathrm{Vg})$ or $(\mathrm{Vp})$ in a population, but still it is a very complex process for exact quantification. There were found to be various other factors that affected in a process of genetic instability. Disruption of stabilizing selection is sometimes suddenly observed in a new region where any population is introduced by man or nature depending on the type of stress given by nature [16]. Due to extreme environmental stress of a new region or sudden change in environmental parameters, developmental instability (DI) and fluctuating asymmetry (FI) is observed where a plant population loses its original homology of floral or vegetative structure from its parent habitat (Figure $1 \&$ Figure 2) [29].

\subsection{Canalization and Developmental Instability}

According to [28], canalization is the process or ability of any organism to produce same phenotype across different environments whereas developmental stability is the ability of a plant or any organism to produce same repetitive phenotype within the same environment. The phenotype may be any vegetative or floral organs of a 
plant. It means overall robustness of the plant or an organism. DH is the result of continuous process of canalizing selection which helps to reduce the accidental phenotypic variation in any region [14] [21] [31].

Developmental stability (DS) shows the processes in a plant that reduce phenotypic variation arising from environmental accidents [32]. Breakdown of developmental stability or homeostasis certainly leads to disruptive selection of the plants and consequently changes in vegetative or reproductive organs [14] [15] [19] [20]. Structural differences of an individual female and hermaphrodite flower found in this region and normally found were given in (Table 1) confirm the developmental instability in a region.

Unique flower morphology and Lerner's hypothesis-According to Lerner's genetic homeostasis model, 7 important hypotheses are to be mentioned [33].

i) Sexually reproducing organisms have certain genotypes that develop self regulating developmental patterns and phenotype.

ii) Genetic composition (variation) that enhances natural fitness of the environment at hand is retained through self equilibrium properties.

iii) Developmental and genetic homeostasis is maintained because of the superiority of the heterozygotes in the population.

iv) The evolution of auto regulation requires the evolution of certain levels of obligate heterozygousity in mendelian populations.

v) The appearance of occasional morphological deviants (Phenodeviants) which as demonstrated by Waddington can arise in response to a change in environment-is linked to heterozygousity as "a certain percentage individuals of every generation falls below the threshold of the obligate proportion of loci needed in a heterozygous state to ensure normal development"

vi) Metric traits result from the inheritance of additively acting polygenic systems.

vii) Natural selection — essentially the sum of past evolutionary history — counteracts against attempts to shift populations too rapidly and/or too far from adaptive means to maintain a phenotypic balance between fitnessdetermining characters.

\subsection{Models and Explanation of Breakdown of Floral Homeostasis}

From the seven hypotheses, the fifth is close for describing the cause DI in floral form in our present investigation. A certain percentage of individuals fall below the threshold of obligate proportion of loci needed for heterozygous state. We presented a model as a contribution to the hypotheses based on legible points about a plant. The plant population which will have minimum amount of heterozygousity undergoes the mutation in one or more genes of co-adaptive gene complexes, causes silent mutation in the complex and does not inhibit the production of necessary proteins or enzymes responsible for floral organogenesis. Especially [34] propounded buffering action of genes and more heterozygousity means more buffering action against adverse environments and he evolved balance theory [34].

\subsection{Basic Configuration of Genes}

Genotype of a plant is $\mathrm{AB} / \mathrm{CD}$ responsible for $\mathrm{FH}$ where gene $\mathrm{A}, \mathrm{B}, \mathrm{C}$, and $\mathrm{D}$ co adaptive gene complexes responsible for flower initiation, development of flower organs, formation of male and female gametes and subsequent maturation of gametes according to their type of sexuality.

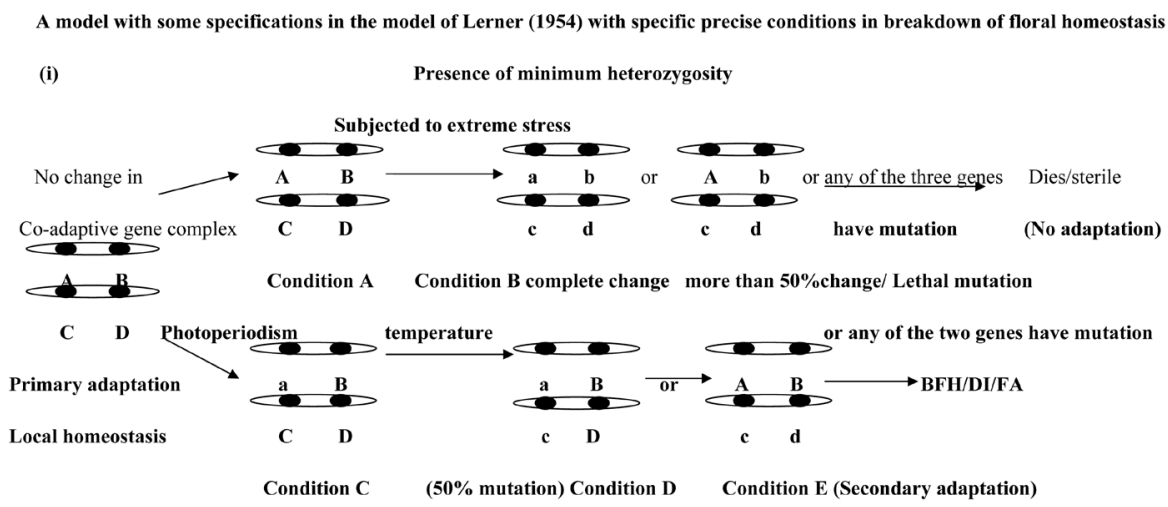


We consider two genes in non-homologous chromosomes responsible for minimum number of genes present for heterozygousity, because one gene in one chromosome does not create any heterozygousity, minimum two genes are required for any heterozygous condition for the formation of co-adaptive gene complex.

i) We assume a condition where more than $50 \%$ of mutation will cause lethality of the plant/organism, it would be difficult to produce flowers or even if flowers are produced, it will have abortive stamen or non functional flower genes which will not produce organs of the flower and the plant/organism will die (first condition). Here mutation is extreme and non functional proteins are produced due to non sense mutation where fitness of population is obstructed.

ii) We also assume the conditions where temperature and photoperiodism will cause particular changes in coadaptive gene complexes and DI/BFH/FA is observed due to shortening of photoperiod length and above the range of average temperature in a particular niche.

(ii) Presence of more heterozygous condition - (Generalised condition)

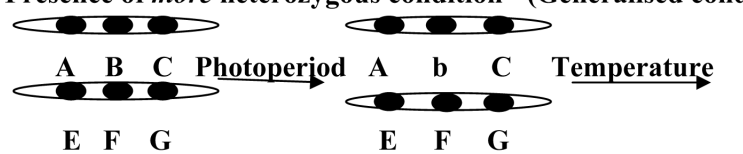

E $\quad$ F $\quad$ G initiation of flowering stage

Silent mutation

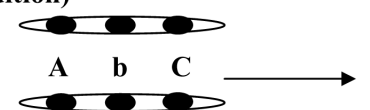

E f G

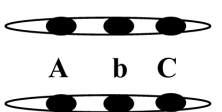

E f $\quad \mathbf{G}$
Local homeostasis

Primary adaptation
Formation of flower

Silent mutation
Production of seeds/fitness of a plant

Secondary adaptation

Mutation specifically silent mutation takes place in producing the desired product of desired genotype of the floral organs, no frame shift or nonsense mutation takes place due to extreme stress of photoperiod and temperature. There must be the end result of the protein or enzyme even low amount or the amount which will help to produce the consistent desired phenotype and effective gametic cells with consistent meiotic divisions even if there are environmental insults like deviation length of photoperiod or heat or any type of abiotic stress impulse have an effect on plant.

Presence of more heterozygous condition (Specific condition)
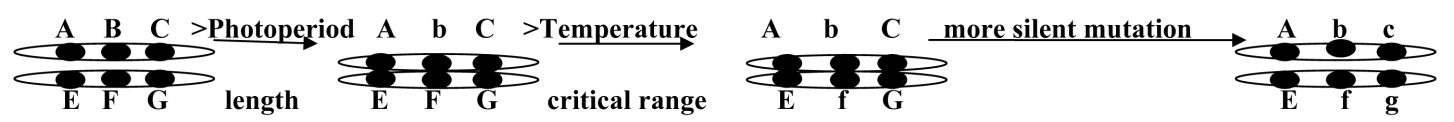

Local homeostasis

initiation of flowering stage

Formation of flower

Formation of BFH/DI/FA/ formation of seeds

Particular length of the photoperiod or temperature range initiates flowering stage of a plant and shifting of vegetative stage to reproductive stage starts on a critical period of length of photoperiod and range of temperature (First condition). More than the critical range of temperature or length of photoperiod will alter the development of flower organs and DI/BFH/FA is found.

\subsection{Flower Dimensions of Female and Hermaphrodite Flowers}

\subsubsection{Correlation Analysis}

The total flower length of female flower was found to be always higher than hermaphrodite flower in all three morphs. Breadth of the sepal and length of the sepal was found to be moderately correlated (0.472) (Table 3) in the correlation matrix assessment although breadth of the sepal was found to be negatively correlated with seed wt per plant $(-0.300)$. Length of the sepal was found to be negatively correlated $(-0.051)$ with seed wt per plant (Table 3).

In case of length of the petal or corolla it was found to be weakly positively correlated with length of the sepal (0.272) and moderately positively correlated with breadth of the sepal (0.511) (Table 3). However length of the petal was found to be strongly negatively correlated with seed wt per plant $(0.845)$ although it was found to be very strongly correlated with breadth of petal (0.956), length of stamen (0.981) length of anther sac (0.739), breadth of anther sac (0.939), flower length (0.959) (Table 3).

In case breadth of corolla, it was found to be strongly negatively correlated with seed wt per plant $(-0.889)$ although it was observed to strongly positively correlated length of stamen (0.950), breadth of anther sac (0.809), 
flower length (0.916) and number of flowers per plant (0.719). Length of style was found to be negatively correlated with all the parameters of flower except in length of stigma (0.295), breadth of the stigma (0.267) and most importantly moderately strong with seed wt per plant (0.561) (Table 3).

\subsubsection{Regression Model}

From the Table A1 (Supplementary Data) and Figures 3(a)-(e), the following interpretations could be gleaned out to reach out the predictions.

a) Number of flowers per plant:

The prediction of seed wt could be done by adopting the regression model where the regression equation would be

$$
Y=-197.6+12.84 * X-0.18 X^{2} \text { (Table A1(a)) (Supplementary data) }
$$

\section{b) Flower length:}

The prediction of seed wt could be interpreted by the regression equation

$$
Y=5.736+10.95 X_{2}-1.076\left(X_{2}\right)^{2} \text { (Table A1(b)) (Supplementary data) }
$$

\section{c) Length of Style:}

The regression equation of length of style would be

$$
Y=408.387-212.17 X_{3}+29.154\left(X_{3}\right)^{2} \text { (Table A1(c)) (Supplementary data) }
$$

\section{d) Length of petal:}

The regression equation

$$
Y=66.134-31.438 X_{4}+5.76 X_{4}{ }^{2} \text { (Table A1(d)) (Supplementary data) }
$$

We found $Y=66.134-31.438 * 3.3+5.76 *(3.3)^{2}=25.115$. This value is also found to be close to the mean value of seed wt within the range of standard deviation value $( \pm 3.1)$ of hermaphrodite plant having entire leaf margin.

\section{e) Breadth of petal:}

Regression equation would be

$$
Y=34.573-1.393 X_{5}-2.775\left(X_{5}\right)^{2}-2.390\left(X_{5}\right)^{3} \text { (Table A1(e)) (Supplementary data) }
$$

\subsection{Difference in Flowering Time of the Plant and Photoperiodism}

During the month of December, the lowest temperature in this region was found $6.4^{\circ} \mathrm{C}$ and highest temperature was recorded $15.1^{\circ} \mathrm{C}$ (Table 4). In February, average temperature gradually increases to $20.1^{\circ} \mathrm{C}$ as highest and lowest was found $10.6^{\circ} \mathrm{C}$. In the month of March, highest temperature was recorded around $24.1^{\circ} \mathrm{C}$ whereas lowest temperature was recorded $12.1^{\circ} \mathrm{C}$. In the month of April, highest temperature was recorded $27.3^{\circ} \mathrm{C}$ whereas lowest was recorded $15.2^{\circ} \mathrm{C}$ (Table 4). But no initiation of flowering was recorded or found in the overall population in the next months in a year. The appropriate location was found in the elevation $1200 \mathrm{~m} \cdot \mathrm{asl}-1500$ m.asl according investigations done previously [10] and also from the present investigation where maximum flowering was observed and positive fecundity was observed in North Eastern Himalayan region from the month of December to April.

The fact of differential time of flower initiation can be reasoned and consequently supported by the studies on phenological variation between population of one species either along latitudinal or elevation gradients [18] or between ecologically distinct habitats [35] and because of low temperature regime and short range of photoperiodism.

One of the important reasons for changes in morphology is environmental stress factors where flower structure changes in a new habitat [14]-[16] [19] (Model 2 and Model 3). The change in floral morphology in our investigation may be distinguished as of environmental stress and genetic stress which would be very significant from the evolution point of view and we showed them in Model 3.

The process of random development of number of petals was found (Figure 1 and Figure 2) to be undergoing breakdown of floral homeostasis (Model 2) due to silent mutation. Environmental stress [15] [19] which causes 
the genetic manipulations and silent mutations in the population ultimately results in breakdown of developmental homeostasis. In this region huge scarcity of rainfall along with low temperature and humidity and short day length (Table 4) was found to imbalance the homeostasis of floral genes (Model 3) and co adaptive gene complexes of the population (Model 3).

We observed three prongs in the upper portion of the stigma (Figure 2) which would draw attention of the pollinators better than earlier settings where three prongs were found in the middle part of the stigma (Table 1) [9] and thus would very likely to enhance the chances pollination and very much significant also from the evolution point of view.

\subsection{Flower Morphological Traits}

\subsubsection{Number of Flowers per Plant}

Asper reports, number of plants was found to have certain direct influence on the seed setting of the plant [22] [36]. The prediction of seed setting in a plant could be done from the regression equation

$$
Y=-197.6+12.837 X_{1}-0.18\left(X_{1}\right)^{2}
$$

Now the plant was found to survive well in temperate region and it was found here also when newly introduced in this region. This regression model could be applicable to anywhere in the world where the plant survives well. Although the co-efficient of determination was found to be not so strong (0.395) (Figure 3(a)), the results was fairly fitted in the regression line and $\mathrm{F}$ value was also found to significant. The number of flowers per plant both in hermaphrodite and female plant was found, so prediction of seed setting per plant could be done in a new habitat as well in a natural habitat of the plant [22] [36].

\subsubsection{Length of Flower}

Length of flower was found to have effect in the seed setting of a plant. The regression equation was found

$$
Y=5.736+10.95 X_{2}-1.076\left(X_{2}\right)^{2}
$$

where the prediction of seed wt could be ascertained when length of flower was found. The coefficient of determination in the scatter diagram (Figure 3(b)) was 0.751 which was quite strong and the performed the goodness of fit in the regression line. The $\mathrm{F}$ value in the $\mathrm{F}$ table and other co-efficients of independent variables in the $\mathrm{t}$ table was also found to be significant. The equation was found to be universally acceptable when by applying known flower length; the prediction of seed set per plant could be ascertained [27].

\subsubsection{Length of Petal}

Length of corolla or petal was found to have influence on seed setting. [27] investigated the relationship with corolla length with fruit parameter and found a linear relationship with them. The coefficient of determination was found 0.295. (Figure 3(c)) which was not so strong, but the F value was found to be significant and also intercept, coefficient of style length and it's square values were found to be significant in the "t" table. The regression equation was

$$
Y=66.134-31.438 X_{4}+5.76\left(X_{4}\right)^{2} .
$$

The regression equation was universally acceptable as this was found significant in its natural habitat and also its introduced region. The prediction of seed set could be done adopting the regression model.

\subsubsection{Breadth of Petal}

Breadth of was found to have influence on the seed wt of the plant and in this case regression equation was found to be

$$
Y=34.573-1.393 X_{5}-2.775\left(X_{5}\right)^{2}-2.390\left(X_{5}\right)^{3}
$$

where $3^{\text {rd }}$ degree polynomial equation was adopted because regressors were found to be better fitted in the regression line. The co efficient of determination was found in the scatter diagram (Figure 3(d)) 0.716 where it was found quite strong and more than $70 \%$ regressors or independent variable could explain the regression line. The prediction of seed wt per plant could be done after adopting the regression model. 


\subsubsection{Length of Style}

Length of style was found to have effect in seed setting in a plant and its length facilitates the process of pollination by pollinators. The trifid stigma was found in female plant and chances of pollination would be more in female plant. Polynomial regression equation was found $Y=408.387-212.17 X_{3}+29.154\left(X_{3}\right)^{2}$. The co efficient of determination was found in scatter diagram (Figure 3(e)) which was not so strong although the F-test confirmed significance at $5 \%$ level of significance. The prediction of seed set could also be possible from the length of style. Now the other factors were very much important for prediction which should also be carefully considered.

\subsection{Genetic Factors Responsible to Gateway of New Flower Morphology}

In connection to the genes governing the floral morphology, earlier it was an accepted idea that flowers are relatively constant because of the genetic homogeneity of the genes that regulate the flower morphology [37]-[39] postulated that 'a genic balance or equilibrium for unknown reason is adaptive and is maintained by natural selection.' He was close to one of the ideas of Lerner's seven hypotheses. [40] investigated the constancy of pentamerous corolla in a Linanthus sps generation after generation where he found great degree of variability in floral organs and number of petals when they were exposed to simulation hervivory. [26] found heritability of floral traits in Penstemon centranthifolius in future generations. [41] observed developmental instability and fluctuating asymmetry in floral forms in Brassica campestris family which indicated the changes in floral structures or breakdown of floral homeostasis. [41] reported that it was a case of genetic phenomenon under extreme selection pressure and carried out generation after generation. However detailed study of genetic effect on developmental instability is still not extensively done, only the level of asymmetry was calculated in some cases of quantification of the level of developmental instability in a particular area of research [42].

\section{Conclusions}

1) Female and hermaphrodite population of all three morphs was found to have unique morphology of flower having four and five number of corollas in the same plant in this North eastern Himalayan region. The random change in floral morphology was the example of disruptive selection of nature under extreme environmental stress in the month of December in this part of the world. The breakdown of canalisation initiates extreme changes in gene complexes of reproductive organs in this new region (Model 3).

2) Length of petal, breadth of petal, length of style, flower length and number of flowers were found to have contributing effects on seed setting of a plant where dimensions of each one of them was found to have effects on seed setting in a new region. Some of the floral traits were found to have direct significant relation and influence on cumulative seed setting of an individual plant.

3) From the evolution point of view, this plant survives well in this region, but changes in flower morphology in both sexes of the plant indicates breakdown in genetic homeostatsis in certain environmental conditions of the plant in this region. This investigation has further scopes if selection of lines of those plants having both types of flowers will be done and consequently observe the pattern of heredity of those characters in future generations.

\section{Acknowledgements}

The authors are grateful to ex-Director, Professor Satyabrata Maiti, present Director Professor Jitendra Kumar, Directorate of Medicinal and Aromatic Plants (DMAPR), Indian Council of Agricultural Research (ICAR), Boriavi, Anand, for financial help and moral support to carry on the conservation programme effectively in this region. The technical help of Mrs Geeta Sharma and Mr. Mahesh Gurung of Regional Research Sation kalimpong and Subrata Manna of Darjeeling Krishi Vigyan Kendra are also acknowledged and without their effort in the field and technical work, the investigation could not be completed effectively.

\section{Conflict of Interest}

The author(s) declare(s) that there is no conflict of interest regarding the publication of this manuscript.

\section{References}

[1] CAMP (2003) Conservation Assessment and Management Prioritization: For the Medicinal Plants of Himachal Pra- 
desh, Jammu and Kashmir and Uttarakhand. Foundation for Revitalization. Foundation of Revitalization of Local Health Traditions (FRLHT), Bangalore.

[2] Jugran, A., Bhatt, I.D., Ranbir, R.S., Nandi, S.K. and Pande, V. (2013) Patterns of Morphological and Genetic Diversity of Valeriana jatamansi Jones in Different Habitats and Altitudinal Range of West Himalaya. Flora, 208, 13-21. http://dx.doi.org/10.1016/j.flora.2012.12.003

[3] Mabberley, D.J. and Noltie, H.J. (2014) A Note on Valeriana jatamansi Jones (Caprifoliaceae s.l.). Blumea, 59, 37-41. http://dx.doi.org/10.3767/000651914X683476

[4] Badola, H.K. and Pal, M. (2002) Endangered Medicinal Plant Species in Himachal Pradesh. Current Science, 83, 797-798.

[5] Jain, S.K. (1968) Medicinal Plants. National Book Trust India, New Delhi, 154.

[6] Chakraborty, S., Mukherjee, D. and Baskey, S. (2015). Indian Valerian, a Highly Endangered Medicinal Plant in North Eastern Himalayan Region. Advances in Plants and Agricultural Research, 2, 00058. http://dx.doi.org/10.15406/apar.2015.02.00058

[7] Prakash, V. (1999) Indian Valerianaceae. A Monograph on Medicinally Important Family. Scientific Publishers, Jodhpur.

[8] Bell, C.D. (2004) Preliminary Phylogeny of Valerianaceae (Dipsacales) Inferred from Nuclear and Chloroplast DNA Sequence Data. Molecular Phylogenetics and Evolution, 31, 340-350. http://dx.doi.org/10.1016/j.ympev.2003.07.006

[9] Nawchoo, A.I., Rather, M.A., Ganie, H.A. and Jan, R.T. (2012) Need for Unprecedented Impetus for Monitoring and Conservation of Valeriana jatamansi, a Valuable Medicinal Plant of Kashmir Himalaya. Agricultural Science Research Journals, 2, 369-373. http://resjournals.com/journals/agricultural-science-research-journal

[10] Rather, A.M., Nawchoo, I.A., Wani, A.A. and Ganie, A.H. (2011) Effect of Habitat Diversification and Temperature on Valeriana jatamansi. New York Science Journal, 4, 57-59. http://www.sciencepub.net/newyork

[11] Chakraborty, S. (2013) Unpublished Data of Valeriana jatamansi. Regional Research Station, Kalimpong, Uttar Banga Krishi Viswavidyalaya.

[12] Anonymous (2013) Annual Report. DMAPR 2012-13, 39. www.dmapr.org.in

[13] Anonymous (2014) Annual Report. DMAPR 2013-14, 45-46. www.dmapr.org.in

[14] Fenster, C.B. and Galloway, L.F. (1997) Developmental Homeostasis and Floral Form: Evolutionary Consequences and Genetic Basis. International Journal of Plant Sciences, 158, S121-S130. http://dx.doi.org/10.1086/297512

[15] Heuther Jr., C.A. (1968) Exposure of Natural Genetic Variability Underlying the Pentamerous Corolla Constancy in Linanthus androsaceous ssp. Androsaceous. Genetics, 60, 123-146.

[16] Cresswell, J.E. (1998) Stabilizing Selection and Structural Variability of Flowers within Species. Annals of Botany, 81, 463-473. http://dx.doi.org/10.1006/anbo.1998.0594

[17] Anderson, S. and Widen, B. (1993) Pollinator-Mediated Selection on Floral Traits in a Synthetic Population of Senecio integrifolius (Asteraceae). Oikos, 66, 72-79. http://dx.doi.org/10.2307/3545197

[18] Mooney, H.A. and Billings, W.D. (1961) Comparative Physiological Ecology of Arctic and Alpine Populations of Oxyria digyna. Ecological Monographs, 31, 1-29. http://dx.doi.org/10.2307/1950744

[19] Barret, S.C.H. and Harder, L.D. (1992) Floral Variation in Eichhornia paniculata (Spreng.) Solms (Pontederiaceae). Effects of Development and Environment on the Formation of Selfing Flowers. Journal of Evolutionary Biology, 5, 83-107. http://dx.doi.org/10.1046/j.1420-9101.1992.5010083.x

[20] Macnair, M.R and Cumbes, Q.J. (1990) The Pattern of Sexual Resource Allocation in the Yellow Monkey Flower, Mimulus guttatus. Proceedings of the Royal Society of London. Series B, 242, 101-107. http://dx.doi.org/10.1098/rspb.1990.0111

[21] Schlumpberger, O.B., Coccuci, A.A., Marcela, M., Sersic, N.A. and Raguso, R. (2009) Extreme Variation in Floral Characters and Its Consequences for Pollinator Attraction among Populations of an Andean Cactus. Annals of Botany, 103, 1489-1500. http://dx.doi.org/10.1093/aob/mcp075

[22] Carlsen, M.T., Espeland, E.K. and Pavlik, M.B. (2002) Reproductive Ecology and the Persistence of an Endangered Plant. Biodiversity and Conservation, 11, 1247-1268. http://dx.doi.org/10.1023/A:1016066618824

[23] Primack, R.B. (1987) Relationships among Flowers, Fruits and Seeds. Annual Review of Ecology and Systematics, 18, 409-430. http://dx.doi.org/10.1146/annurev.es.18.110187.002205

[24] Horvitz, C.C. and Schemske, W.D. (1990) Spatiotemporal Variation in Insect Mutualists of a Neotropical Herb. Ecology, 71, 1085-1097. http://dx.doi.org/10.2307/1937377

[25] Pérez, F., Arroyo, T.K.M., Rodrigo, M. and Hershkovitz, M.A. (2006) Ancestral Reconstruction of Flower Morphology and Pollination Systems in Schizanthus (Solanaceae). American Journal of Botany, 93, 1029-1038. http://dx.doi.org/10.3732/ajb.93.7.1029 
[26] Mitchell, R.J. and Shaw, R.J. (1993) Heritability of Floral Traits for the Perennial Wild Flower Penstemon centranthifolius (Scorphulariaceae): Clones and Crosses. Heredity, 71, 185-192. http://dx.doi.org/10.1038/hdy.1993.123

[27] Primack, R.B. (1985) Patterns of Flowering Phenology on Communities, Individuals and Single Flowers. In: White, J., Ed., The Population Structure of Vegetation, Dr W. Junley Publishers, Dordrecht, 571-593. http://dx.doi.org/10.1007/978-94-009-5500-4 24

[28] Waddington, C.H. (1942) Canalization of Development and Inheritance of Acquired Characters. Nature, 150, $563-565$. http://dx.doi.org/10.1038/150563a0

[29] Lerner, I.M. (1954) Genetic Homeostasis. Oliver and Boyd, London.

[30] Pertoldi, C., Kristensen, T.N., Andersen, D.H. and Loeschcke, V. (2006) Developmental Instability as an Estimator of Genetic Stress. Heredity, 96, 122-127. http://dx.doi.org/10.1038/sj.hdy.6800777

[31] Waddington, C.H. (1940) Organizers and Genes. Cambridge University Press, Cambridge.

[32] Zakharov, V.M. (1989) Future Prospects for Population Phenogenetics. Soviet Scientific Reviews, Sec. F, Physiology and General Biology Reviews, 4, 1-79.

[33] Hall, B.K. (2005) Fifty Years Later: I. Michael Lerner’s Genetic Homeostasis (1954)—A Valiant Attempt to Integrate Genes, Organisms and Environment. Journal of Experimental Zoology Part B: Molecular and Developmental Evolution, 304B, 187-197.

[34] Dobzhansky, T. and Wallace, B. (1953) The Genetics of Homeostasis in Drosophila. Proceedings of the National Academy of Sciences of the United States of America, 39, 162-171. http://dx.doi.org/10.1073/pnas.39.3.162

[35] Lack, J.A. (1982) Competition for Pollinators in the Ecology of Centaurea scabiosa L. vs Centaurea nigra L.I. Variation in Flowering Time. New Phytologist, 91, 297-308. http://dx.doi.org/10.1111/j.1469-8137.1982.tb03314.x

[36] Campbell, D.R. (1996) Evolution of Floral Traits in a Hermaphroditic Plant: Field Measurements of Heritabilities and Genetic Correlations. Evolution, 50, 1442-1453. http://dx.doi.org/10.2307/2410882

[37] Siikamaki, P. (1999) Developmental Instability in Hybrids between Lychnis viscaria and Lychnis alpina (Caryophyllaceae). American Journal of Botany, 86, 1683-1686. http://dx.doi.org/10.2307/2656666

[38] Schmalhausen, I.I. (1949) Factors of Evolution. The Theory of Stabilizing Selection. Blakiston, Philadelphia, 326.

[39] Stebbins, G.L. (1974) Flowering Plants: Evolution above the Species Level. Edward Arnold, London. http://dx.doi.org/10.4159/harvard.9780674864856

[40] Heuther Jr., C.A. (1969) Constancy of the Pentamerous Corolla Phenotype in Natural Populations of Linanthus. Evolution, 23, 572-588. http://dx.doi.org/10.2307/2406854

[41] Evans, A.S. and Marshall, M. (1996) Developmental Instability in Brassica campestris (Cruciferae). Fluctuating Asymmetry of Foliar Floral Traits. Journal of Evolutionary Biology, 9, 717-736. http://dx.doi.org/10.1046/j.1420-9101.1996.9060717.x

[42] Moller, P.A. and Shykoff, J.A. (1999) Morphological Developmental Stability in Plants: Patterns and Causes. International Journal of Plant Science, 160, S135-S146. http://dx.doi.org/10.1086/314219 


\section{Supplementary Data}

\section{ANOVAs of the Regression}

Except in case of style length, all the parameters were found to have negative $\mathrm{R}^{2}$ value in linear model of regression and for that reason linear model of regression were discarded. Even in style length also, the value of multiple regression co efficient, adjusted $\mathrm{R}^{2}$ values of linear regression model were found to be less compared to polynomial regression and for that reason independent variable style length was taken for polynomial regression model against seed wt for better suited curvilinear diagram.

Adjusted $\mathrm{R}^{2}$ values and standard error of the parameters were calculated to find out the best fitted regression line in the scatter diagram. The value of intercept in each case was found along with standard error and $\mathrm{p}$ value for the regression equation of the overall result.

The equation is $Y=a+b_{1} X_{1}+b_{2} X^{2}$, a $2^{\text {nd }}$ order polynomial regression equation.

$Y=$ dependant variable $X_{1}, X_{2}, X_{3}, \cdots, X_{5}$ etc. = independent variables of the flower parameters.

The $3^{\text {rd }}$ order polynomial regression was found to be appropriate in breadth of petal where $2^{\text {nd }}$ order polynomial regression was found to have less $R^{2}$ value $(0.415)$ than $3^{\text {rd }}$ order regression output where $R^{2}$ value was found in the scatter diagram.

The equation is

$$
Y=a X_{1}+b X_{1}+c X_{1}^{2}+d X_{1}^{3}
$$

In case of parameters like length of sepal, breadth of sepal, length of stigma, breadth of stigma, length of stamen, length of anther sac, breadth of anther sac, they all found to have negative $r^{2}$ values in linear quadratic model as we as they were found to have very weak positive $\mathrm{R}^{2}$ values in polynomial regression equation as well as adjusted $\mathrm{R}^{2}$ values, and for that reason they were discarded for regression model analysis due to non significant and invalid prediction.

5 independent variables were taken which were found to be best fitted to the curvilinear equation in regression analysis.

"a" = individual intercept values of the regression variables $X_{1}, X_{2}, X_{3}, \cdots, X_{5}$ as there were 5 variables taken into consideration found to have best fitted regression relationship which were independent variables of the regression equation.

From the overall model, the following inferences can be gleaned out for evolutionary significances:

1) The scatter diagram and closeness or fitting of data in the regression line.

2) The overall model is significant or not (calculated $F$ value against tabulated $F$ value).

3) The values of $R^{2}$ and adjusted $R^{2}$.

\section{Number of Flowers per Plant}

1) The overall model is significant at $5 \%$ level (significance F value $0.274>0.05$ ) Table A1(a) (Supplementary data). The fitted regression line (Figure 3(a)) was found significant and seed wt per plant can be predictable by regression equation.

2) $R^{2}$ was 0.578 and adjusted $R^{2} 0.297$ which was found fairly positive.

Regression equation would be

$$
\begin{gathered}
Y=-197.6+12.837 X_{1}-0.18 X_{1}^{2} \\
Y=-197.6+12.84 \times 40-0.18 \times(40)^{2}=-197.6+513.6-288=28
\end{gathered}
$$

the prediction of seed wt would be $28 \mathrm{mg}$ if $X$ variable is 40 , that is number of flowers per plant.

3) The value $R^{2}$ was 0.758 and adjusted $R^{2}$ was 0.597 both of which were strongly positive.

\section{Flower Length}

In case of flower length, from the ANOVA Table A1(b) it was found highly significant where F value was found higher than tabulated value (Significance F 0.119 > 0.05) (Table A1(b)).

From the scatter diagram the results were found to be finely fitted in the parabolic line of polynomial regression (Figure 3(b)). 
Table A1. Regression table and ANOVA of (a) Number of flowers per plant and seed yield, (b) Flower length and seed yield, (c) Length of style and seed yield, (d) Length of corolla and seed yield, (e) Breadth of corolla and seed yield.

(a)

\begin{tabular}{|c|c|c|c|c|c|}
\hline \multicolumn{6}{|c|}{ Regression Statistics } \\
\hline Multiple R & 0.761 & & & & \\
\hline R Square & 0.578 & & & & \\
\hline Adjusted R Square & 0.297 & & & & \\
\hline Standard Error & 4.039 & & & & \\
\hline \multirow[t]{3}{*}{ Observations } & 6 & & & & \\
\hline & & ANOVA & & & \\
\hline & df & SS & MS & $\mathrm{F}$ & Significance F \\
\hline Regression & 2 & 67.147 & 33.573 & 2.058 & 0.274 \\
\hline Residual & 3 & 48.933 & 16.311 & & \\
\hline Total & 5 & 116.080 & & & \\
\hline
\end{tabular}

(b)

\begin{tabular}{|c|c|c|c|c|c|c|}
\hline \multicolumn{7}{|c|}{ Regression Statistics } \\
\hline Multiple R & 0.871 & & & & & \\
\hline R Square & 0.758 & & & & & \\
\hline Adjusted R Square & 0.597 & & & & & \\
\hline Standard Error & 3.057 & & & & & \\
\hline \multirow[t]{3}{*}{ Observations } & 6 & & & & & \\
\hline & & ANOVA & & & & \\
\hline & $d f$ & SS & MS & $F$ & Significance F & \\
\hline Regression & 2 & 88.03 & 44.02 & 4.71 & 0.11 & \\
\hline Residual & 3 & 28.04 & 9.34 & & & \\
\hline \multirow[t]{2}{*}{ Total } & 5 & 116.08 & & & & \\
\hline & Coefficients & Standard Error & t Stat & P-value & Lower 95\% & Upper 95\% \\
\hline Intercept & 5.73 & 19.97 & 0.28 & 0.79 & -57.84 & 69.31 \\
\hline Flower length ${ }^{2}$ & -1.07 & 0.67 & -1.59 & 0.20 & -3.22 & 1.06 \\
\hline Flower length & 10.95 & 7.84 & 1.39 & 0.25 & -14.00 & 35.91 \\
\hline
\end{tabular}

(c)

\begin{tabular}{|c|c|c|c|c|c|c|}
\hline \multicolumn{2}{|c|}{ Regression Statistics } & & & & & \\
\hline Multiple R & 0.687 & & & & & \\
\hline R Square & 0.472 & & & & & \\
\hline Adjusted R Square & 0.120 & & & & & \\
\hline Standard Error & 4.519 & & & & & \\
\hline \multirow[t]{3}{*}{ Observations } & 6 & & & & & \\
\hline & & ANOVA & & & & \\
\hline & $d f$ & SS & $M S$ & $F$ & Significance F & \\
\hline Regression & 2 & 54.81 & 27.40 & 1.342 & 0.38 & \\
\hline Residual & 3 & 61.27 & 20.42 & & & \\
\hline \multirow[t]{2}{*}{ Total } & 5 & 116.08 & & & & \\
\hline & Coefficients & Standard Error & t Stat & $P$-value & Lower 95\% & Upper 95\% \\
\hline Intercept & 408.38 & 478.93 & 0.85 & 0.45 & -1115.78 & 1932.56 \\
\hline Length of style ${ }^{2}$ & 29.15 & 33.45 & 0.87 & 0.44 & -77.30 & 135.61 \\
\hline Length of style & -212.17 & 254.03 & -0.83 & 0.46 & -1020.63 & \\
\hline
\end{tabular}


(d)

\begin{tabular}{|c|c|c|c|c|c|c|}
\hline \multicolumn{7}{|c|}{ Regression Statistics } \\
\hline Multiple R & 0.897 & & & & & \\
\hline R Square & 0.805 & & & & & \\
\hline Adjusted R Square & 0.676 & & & & & \\
\hline Standard Error & 2.744 & & & & & \\
\hline \multirow[t]{3}{*}{ Observations } & 6 & & & & & \\
\hline & & ANOVA & & & & \\
\hline & $d f$ & SS & $M S$ & $F$ & Significance $F$ & \\
\hline Regression & 2 & 93.497 & 46.748 & 6.210 & 0.086 & \\
\hline Residual & 3 & 22.583 & 7.528 & & & \\
\hline \multirow[t]{2}{*}{ Total } & 5 & 116.08 & & & & \\
\hline & Coefficients & Standard Error & t Stat & P-value & Lower 95\% & Upper 95\% \\
\hline Intercept & 66.134 & 23.584 & 2.804 & 0.068 & -8.921 & 141.190 \\
\hline Length of corolla ${ }^{2}$ & 5.760 & 4.872 & 1.182 & 0.322 & -9.744 & 21.265 \\
\hline Length of corolla & -31.438 & 22.900 & -1.373 & 0.263 & -104.314 & 41.439 \\
\hline
\end{tabular}

(e)

\begin{tabular}{|c|c|c|c|c|c|c|}
\hline \multicolumn{7}{|c|}{ Regression Statistics } \\
\hline Multiple R & 0.897 & & & & & \\
\hline R Square & 0.805 & & & & & \\
\hline Adjusted R Square & 0.676 & & & & & \\
\hline Standard Error & 2.744 & & & & & \\
\hline \multirow[t]{3}{*}{ Observations } & 6 & & & & & \\
\hline & & ANOVA & & & & \\
\hline & $d f$ & SS & MS & $F$ & Significance F & \\
\hline Regression & 2 & 93.497 & 46.748 & 6.210 & 0.086 & \\
\hline Residual & 3 & 22.583 & 7.528 & & & \\
\hline \multirow[t]{2}{*}{ Total } & 5 & 116.08 & & & & \\
\hline & Coefficients & Standard Error & t Stat & $P$-value & Lower 95\% & Upper $95 \%$ \\
\hline Intercept & 66.134 & 23.584 & 2.804 & 0.068 & -8.921 & 141.190 \\
\hline Breadth of corolla ${ }^{2}$ & 5.760 & 4.872 & 1.182 & 0.322 & -9.744 & 21.265 \\
\hline Breadth of corolla & -31.438 & 22.900 & -1.373 & 0.263 & -104.314 & 41.439 \\
\hline
\end{tabular}

From Table A1(b), the regression equation would be $Y=5.736+10.95 X_{2}-1.076 X_{2}^{2}$.

Putting the value flower length in the equation, we found

$$
Y=5.736+10.95 \times 8.4-1.076 \times 70.56=21.793 .
$$

\section{Length of Style}

In case length of style, from the Figure 3(c), the regression statistical model for polynomial regression was 
found to be significant from the F table (Significance F $0.38>0.05$ ) (Table A1(c)).

Here intercept, length of style, length of style ${ }^{2}$ were all also found to be significant in " $\mathrm{t}$ " table at $95 \%$ level of significance.

From Table A1(c), the regression equation would be $Y=408.387-212.17 X_{3}+29.154 X_{3}^{2}$

Putting the value of length of style we get

$$
Y=408.387-212.17 \times 3.4+29.15 \times(3.4)^{2}=23.98
$$

It is close to the mean value of seed wt 24.3 and within the range of standard deviation value $( \pm 3.1)$ of hermaphrodite plants having entire leaf margin.

Regression statistics was found to be significant after observing significance $F$ value $(0.086>0.05)$ (Table $\mathrm{A} 1(\mathrm{~d}))$. All the values of intercept, length of petal and length of petal ${ }^{2}$ were all significant in " $\mathrm{t}$ " table at $95 \%$ level of significance.

Regression equation would be $Y=66.134-31.438 X_{4}+5.76 X_{4}^{2}$;

Putting the values of length of corolla of hermaphrodite plant having entire leaf margin, $Y=25.115$.

\section{Breadth of the Petal}

In this parameters also breadth of petal was found significant (Significance F $0.269>0.05$ ) (Table A1(e)) (Supplementary data). Here intercept, breath of petal, breadth of petal ${ }^{2}$ and breadth of petal ${ }^{3}$ were all significant in " $\mathrm{t}$ " table at $95 \%$ level of significance.

$$
Y=34.573-1.393 X_{5}-2.775 X_{5}^{2}-2.390 X_{5}^{3} .
$$

Regression equation would be $Y=34.573-1.393 X_{5}-2.775 X_{5}^{2}-2.390 X_{5}^{3}$.

Putting the value of breadth of petal of hermaphrodite plant having entire leaf margin, we found

$$
Y=34.573-1.393 \times 1.2-2.775 \times(1.2)^{2}-2.390 \times(1.2)^{3}=24.775
$$

this value is also found to be close the mean value of seed wt within the range of standard deviation value $( \pm 3.1)$ of hermaphrodite plant having entire leaf margin. 